\title{
Policy Implementation on Guidelines for New Habits Adaptation Lampung Province: Survey on Student Groups
}

\author{
Simon Sumanjoyo Hutagalung \\ Public Administration \\ Lampung University \\ Lampung, Indonesia \\ simon.sumanjoyo@fisip.unila.ac.id
}

\author{
Himawan Indrajat \\ Governance Science \\ Lampung University \\ Lampung, Indonesia \\ himawan.indrajat@fisip.ac.id
}

\begin{abstract}
Various efforts have been made by the government and implemented into the community to overcome the impact of the pandemic, one of which is Lampung Governor Regulation Number 45 of 2020 concerning Guidelines for New Habits Adaptation Towards a Productive and Safe Society for Corona Virus Disease 2019 (Covid-19) in Lampung Province. Analysis of the implementation of this policy is needed to generate input on the ability to implement the policy. An essential group to be involved in assessing the policy are students. The research was conducted through an open survey made with a google form and disseminated to students in Lampung Province. The questionnaire was distributed between April 5 and May 5, 2021, and distributed through social media and online networks concerned with handling the pandemic in Lampung Province. Questionnaires were distributed to members of the five social media accounts and online networks with a snowball. The data obtained from the google form is recapitulated according to the order of variables and indicators, then verification is carried out on the consistency of filling in the answers. Data that does not fully answer the question is then selected, while intact
\end{abstract}

data is maintained. Furthermore, the data analysis process was carried out quantitatively descriptively using the MS Excel application.

Keywords-Public Policy, Implementation, Pandemic Handling, Students

\section{INTRODUCTION}

The pandemic had an impact on various aspects of society, including government, education, and socioeconomics. Various efforts were made by the government and implemented into the community to overcome the impact of the widespread pandemic [1]. One of the policies formulated and implemented in the Lampung Province is through Lampung Governor Regulation Number 45 of 2020 concerning Guidelines for New Habits Adaptation Towards a Productive and Safe Society for Corona Virus Disease 2019 (Covid-19) in Lampung Province. This regulation has several scopes and primary substances, which can be observed in the following table:

TABLE I. SCOPE AND MAIN SUbSTANCE ON GOVERNOR OF LAMPUNG PROVINCE REgUlation Number 45 OF 2020

\begin{tabular}{|c|l|l|}
\hline No & \multicolumn{1}{|c|}{ Scope of } & \multicolumn{1}{c|}{ Principal Substance } \\
\hline 1 & $\begin{array}{l}\text { Implementation of AKB-M2PA } \\
\text { COVID-19; }\end{array}$ & $\begin{array}{l}\text { cultivate social discipline behavior in outdoor activities for everyone who is } \\
\text { domiciled and has activities in the Lampung area through the COVID-19 health } \\
\text { protocol }\end{array}$ \\
\hline 2 & $\begin{array}{l}\text { Residents' rights and obligations } \\
\text { in AKB-M2PA COVID-19 }\end{array}$ & $\begin{array}{l}\text { Rights to: (a). essential health services according to medical needs; (b). public data } \\
\text { and information regarding COVID-19; (c). easy access to make complaints about } \\
\text { COVID-19; and (d). relocation and burial services for COVID-19 and suspected } \\
\text { COVID-19 corpses. }\end{array}$ \\
\cline { 3 - 4 } & $\begin{array}{l}\text { Obligations to: (a). participate in testing and examining samples for COVID-19 in } \\
\text { epidemiological investigations (contact tracing); (b). self-isolate at residence and } \\
\text { quarantine or treatment in a hospital under the Regency/City Task Force; and (c). } \\
\text { report to health workers if they and their families are exposed to COVID-19. }\end{array}$ \\
\hline 3 & $\begin{array}{l}\text { Resources for handling COVID- } \\
19 ;\end{array}$ & $\begin{array}{l}\text { Provision of databases and information on the need for the provision and distribution } \\
\text { of resources, cooperation in the form of (a). human resource support; (b). facilities } \\
\text { and infrastructure; (c). data and information; and (d). other services and support. }\end{array}$ \\
\hline 4 & $\begin{array}{l}\text { Monitoring, evaluation, and } \\
\text { reporting; }\end{array}$ & $\begin{array}{l}\text { Development, supervision, and control based on data and facts in the field towards } \\
\text { (a). disciplining COVID-19 prevention protocols, and (b). supervision of the } \\
\text { COVID-19 AKB-M2PA in Lampung Province. }\end{array}$ \\
\hline
\end{tabular}




\begin{tabular}{|c|l|l|}
\hline \multirow{2}{*}{} & & $\begin{array}{l}\text { (1). The Provincial Task Force evaluates the implementation of AKB-M2PA in the } \\
\text { COVID-19 situation by the Regency/City Task Force and provides } \\
\text { recommendations for the necessary improvements. (2). Assessment of the success of } \\
\text { the AKB-M2PA implementation in the COVID-19 situation as referred to in } \\
\text { paragraph (1). }\end{array}$ \\
\hline 5 & Sanctions. & $\begin{array}{l}\text { Violations of the implementation of AKB-M2PA in the COVID-19 situation are } \\
\text { subject to administrative sanctions and police coercion. (2). The administrative } \\
\text { sanctions, as referred to in paragraph (1), consist of (a). verbal warning; (b). written } \\
\text { reprimand; (c). temporary suspension of activities; (d). permanent cessation of } \\
\text { activities; (e). temporary revocation of license; and (f). permanent revocation of } \\
\text { license. (3) Police coercion, as referred to in paragraph (1), consists of (a). cleaning } \\
\text { public facilities such as sweeping streets and picking up trash; (b). sing the National } \\
\text { anthem; (c). to do push-ups, and D). promise not to violate health protocols. }\end{array}$ \\
\hline
\end{tabular}

The Governor's Regulation is a guideline policy and needs to be implemented. Policy implementation in principle is a way for a policy to achieve its goals, further explained that nothing more and nothing less [2]. Implementation involves an assessment of the actions that have been programmed that are satisfactory. Implementation refers to actions to achieve the goals that have been set in a decision. This action seeks to turn these decisions into operational patterns and achieve major or minor changes as previously decided [3]. Implementation is essentially an effort to understand what should happen after the program is implemented. In practical terms, implementation is the process of implementing decisions that have various objectives [4]. Analysis of the implementation of this policy is needed to generate input on the ability to implement the policy. An essential group to be involved in assessing the policy are students. The role of students as agents of change is perhaps the most frequently voiced by students when making changes related to government policies [5]. Students are agents of change who must stand at the forefront of voicing the aspirations of the people. Related to the policy, the formulation of the problem in this study are: (1). What is the perception of the student group towards the implementation of the new habit adaptation policy towards a productive and safe society for coronavirus disease 2019 (Covid-19) in Lampung Province, (2) What aspects need to be improved to optimize the implementation of the New Habit Adaptation Policy Towards a Productive and Safe Society for Corona Virus Disease 2019 (Covid-19) in Lampung Province?

\section{LITERATURE REVIEW}

The implementation process itself contains a very complex and lengthy process. The implementation process begins when the policy is established or has a valid legal umbrella. After that, the implementation stages begin with a series of activities to process regulations, establish organizations, resources, technology, establish procedures, and the stated policy objectives being realized [6]. Therefore, the implementation stage as a process to realize policy objectives is often called a critical stage because it is a liaison or bridge between two concepts and the world of reality [7].

George C. Edward III's Policy Implementation Model, a top-down perspective model, was developed by George C. Edward III. The model has four variables that determine the success of implementing a policy, namely: (1) communication, (2) resources, (3) disposition, and (4) bureaucratic structure. The four variables can be applied in the following approach model: The first variable that affects the successful implementation of a policy, according to George C. Edward III, is communication. According to Edward III, communication indicates that every policy can be carried out properly if there is effective communication between program implementers (policies) and the target group (target group) [8]. The goals and objectives of the program/policy can be appropriately socialized to avoid distortions (misunderstandings) of policies and programs. It is essential because the higher the target group's knowledge of the program, the lower the level of rejection and error in applying programs and policies in the real world.

The second variable that affects the successful implementation of a policy is resources. According to Edward III, resources appointing every policy must be supported by adequate human resources and financial resources [9]. Human resources are the adequacy of both quality and quantity of implementers that can cover the entire target group. Furthermore, according to George C. Edward III, the failure that often occurs in policy implementation is partly due to insufficient, adequate, or incompetent resources in their field [10]. The number of resources alone is not enough, but it is also necessary to have sufficient resources with the necessary skills and abilities to implement policies. According to George C. Edward III, financial resources are the adequacy of investment capital for a program/policy. Both must be considered in the implementation of government programs/policies [11].

The third variable that affects the successful implementation of a policy is disposition. According to Edward III, disposition shows characteristics closely attached to the implementor of policies/programs [8]. The most important characters possessed by the implementer are honesty, commitment, and democracy. Implementors who have a high commitment and honesty will always survive among the obstacles encountered in the program/policy. Honesty directs implementors to stay in the program's direction that has been outlined in the program guidelines (framework). The commitment and honesty of the implementer made him more enthusiastic in implementing the program stages consistently [4]. A democratic attitude will increase the excellent impression of the implementor and the policy in front of the target group members. This attitude will reduce resistance from the community and foster a sense of trust and concern for the target group towards implementers and programs/policies [12]. 
The fourth variable that affects the successful implementation of a policy is the structure of the bureaucracy. According to Edward III, the bureaucratic structure indicates that the bureaucratic structure is vital in policy implementation. This aspect of the bureaucratic structure includes two essential things: the mechanism and organizational structure of the implementing organization itself [7]. The program implementation mechanism is usually set through a Standard Operating Procedure (SOP) and is easily understood by those listed in the program/policy guidelines. According to George C. Edward III, when the organizational structure is not conducive to the available policies, some resources will be ineffective and hinder the course of the policy. The four variables above in the model built by Edward III have interrelationships in achieving program/policy goals and objectives [13]. All of them synergize in achieving goals, and one variable dramatically affects the other variables.

\section{RESEARCH METHODS}

The research was conducted through an open survey made using google form and disseminated to students in Lampung Province. The questionnaire was distributed between April 5 and May 5, 2021, and distributed through social media and online networks concerned with handling the pandemic in Lampung Province. Questionnaires were distributed to members of the five social media accounts and online networks with snowball patterns. The population in this research refers to the Lampung in Figures Book, which states that the number of state university students in Lampung until 2020 is 32784 people (BPS, 2021). So by using the Slovin formula: $\mathrm{n}=\mathrm{N} /\left(1+\left(\mathrm{N} \mathrm{x} \mathrm{e}^{2}\right)\right)$, the sample required is 395 respondents who are confirmed to have answered all the questions in the questionnaire. In this study, several relevant variables and indicators were selected and could reflect essential elements in the implementation of public policy. The following are the variables and indicators in the survey:

TABLE II. VARIABLES IN POLICY IMPLEMENTATION ACCORDING TO EDWARD III

\begin{tabular}{|c|c|c|}
\hline No & Variable & Indicators \\
\hline \multirow[t]{3}{*}{1} & \multirow[t]{3}{*}{ Communication } & Information Transmission \\
\hline & & Clarity \\
\hline & & $\begin{array}{l}\text { Consistency in } \\
\text { implementation }\end{array}$ \\
\hline \multirow[t]{4}{*}{2} & \multirow[t]{4}{*}{ Resources } & adequate human resources \\
\hline & & Budget \\
\hline & & Authority \\
\hline & & Implementation facilities \\
\hline \multirow[t]{3}{*}{3} & \multirow[t]{3}{*}{ Disposition } & Implementing Compliance \\
\hline & & Task Fit \\
\hline & & $\begin{array}{l}\text { Implementing } \\
\text { Incentives/Rewards }\end{array}$ \\
\hline \multirow[t]{2}{*}{4} & \multirow{2}{*}{$\begin{array}{l}\text { Bureaucratic } \\
\text { Structure. }\end{array}$} & Availability of SOP \\
\hline & & $\begin{array}{l}\text { Distribution of } \\
\text { responsibilities The }\end{array}$ \\
\hline
\end{tabular}

Data obtained from the google form is recapitulated according to the order of variables and indicators, then verification is carried out on the consistency of filling in the answers. Data that does not fully answer the question is then selected, while intact data is maintained. Furthermore, the data analysis process was carried out quantitatively descriptively using the MS application. Excel. Data in excel format in the form of respondent profiles and answers to variables and indicators are processed in percentages and then presented in the form of table illustrations so that they are easy to explain.

\section{RESULTS AND DISCUSSION}

\section{A. Profile of Respondents}

Based on the questionnaires that have been answered and returned, data related to the profiles of respondents involved in this study can be identified. Details related to some of these identities can be seen from the table below:

TABLE III PROFILE OF RESEARCH RESPONDENTS IMPLEMENTATION OF GOOD HABITS ADAPTATION POLICIES

\begin{tabular}{|c|c|c|c|c|}
\hline No & Category & Total & $\%$ & Total \\
\hline \multirow{3}{*}{1} & \multicolumn{4}{|c|}{ Gender Jenis } \\
\hline & Male & 174 & 44.1 & \\
\hline & Female & 221 & 55.9 & 395 \\
\hline \multirow{3}{*}{2} & \multicolumn{4}{|l|}{ Age Range } \\
\hline & $17-22$ yrs & 359 & 90.9 & \\
\hline & $23-30$ yrs & 36 & 9.1 & 395 \\
\hline \multirow{8}{*}{3} & \multicolumn{4}{|c|}{ Tribes } \\
\hline & Java & 176 & 44.6 & \\
\hline & Lampung & 115 & 29.1 & \\
\hline & Sunda & 22 & 5.6 & \\
\hline & South Sumatra & 43 & 10.9 & \\
\hline & Minangkabau & 14 & 3.5 & \\
\hline & Banten & 6 & 1.5 & \\
\hline & Others & 19 & 4.8 & 395 \\
\hline \multirow{5}{*}{4} & \multicolumn{4}{|c|}{ Origin of The Campus } \\
\hline & Unila & 246 & 62.3 & \\
\hline & UIN & 112 & 28.4 & \\
\hline & Polyfilla & 32 & 8.1 & \\
\hline & Others & 5 & 1.3 & 395 \\
\hline
\end{tabular}

From the table above, it appears that the dominant profile slices of respondents are women (55.9\%), age range $17-22$ years $(90.95)$, Javanese $(44.6 \%)$, and Lampung (29) ethnic backgrounds. 1\%) and the dominant one came from the University of Lampung $(62.3 \%)$. This profile indicates that this research is more attractive to female students, predominantly from the University of Lampung, who are in the early semesters where their passion for learning and analyzing is still strong. From this profile, it is necessary to observe the distribution of the questionnaire results, which is described based on the variables and indicators used.

\section{B. Analysis of Student Perceptions of Policy Implementation}

Edwards III suggests that policy implementation is needed because policy problems need to be addressed and solved. Edwards III introduces an implementation 
problem approach by asking what factors support and hinder the success of policy implementation [14]. According to him, there are four factors as a source of problems and preconditions for the implementation process's success: communication, resources, bureaucratic or executor attitude, and organizational structure, including the flow of bureaucratic work [4]. This factor then becomes the focus of analysis in this research, where the results of the answers from the respondents are presented in the following:

TABLE IV. ANSWERS DiSTRIBUTION ON IMPLEMENTATION OF GUIDELINES FOR ADAPTATION NEW HABITS TOWARDS A PRODUCTIVE AND SAFE SOCIETY CORONA VIRUS DisEASE 2019 (COVID-19) IN LAMPUNG PROVINCE

\begin{tabular}{|c|c|c|c|c|c|c|c|c|c|c|c|c|}
\hline \multirow{2}{*}{ No } & \multirow{2}{*}{ Variable } & \multirow{2}{*}{ Indicators } & \multicolumn{10}{|c|}{ Distribution Answers } \\
\hline & & & Exec & $\%$ & $G$ & $\%$ & $S$ & $\%$ & $L S$ & $\%$ & $P$ & $\%$ \\
\hline \multirow{3}{*}{1} & \multirow{3}{*}{ Communication } & Information Transmission & 30 & 7.6 & 130 & 32.9 & 155 & 39.2 & 65 & 16.5 & 15 & 3.8 \\
\hline & & Clarity & 31 & 7.8 & 125 & 31.6 & 145 & 36.7 & 79 & 20.0 & 15 & 3.8 \\
\hline & & Consistency in implementation & 22 & 5.6 & 126 & 31.9 & 135 & 34.2 & 82 & 20.8 & 30 & 7.6 \\
\hline \multirow{4}{*}{2} & \multirow{4}{*}{ Resources } & adequate human resources & 25 & 6.3 & 147 & 37.2 & 133 & 33.7 & 75 & 19.0 & 15 & 3.8 \\
\hline & & $\begin{array}{l}\text { Information that can be } \\
\text { understood }\end{array}$ & 27 & 6.8 & 132 & 33.4 & 146 & 37.0 & 72 & 18.2 & 18 & 4.6 \\
\hline & & Authority & 24 & 6.1 & 157 & 39.7 & 125 & 31.6 & 71 & 18.0 & 18 & 4.6 \\
\hline & & Implementation facilities & 27 & 6.8 & 130 & 32.9 & 143 & 36.2 & 80 & 20.3 & 15 & 3.8 \\
\hline \multirow{3}{*}{3} & \multirow{3}{*}{ Disposition } & Implementing Compliance & 17 & 4.3 & 138 & 34.9 & 166 & 42.0 & 53 & 13.4 & 21 & 5.3 \\
\hline & & Task Fit & 22 & 5.6 & 139 & 35.2 & 167 & 42.3 & 49 & 12.4 & 18 & 4.6 \\
\hline & & $\begin{array}{l}\text { Implementing } \\
\text { Incentives/Rewards }\end{array}$ & 36 & 9.1 & 130 & 32.9 & 153 & 38.7 & 58 & 14.7 & 18 & 4.6 \\
\hline \multirow{2}{*}{4} & \multirow{2}{*}{$\begin{array}{l}\text { Bureaucratic } \\
\text { Structure. }\end{array}$} & Availability of SOP & 22 & 5.6 & 133 & 33.7 & 152 & 38.5 & 67 & 17.0 & 21 & 5.3 \\
\hline & & Distribution of responsibilities & 32 & 8.1 & 120 & 30.4 & 150 & 38.0 & 78 & 19.7 & 15 & 3.8 \\
\hline
\end{tabular}

From the large table, analysis and explanation of each variable are then carried out to produce more profound conclusions. The explanation of each variable is described in the description below:

\section{1) Communication}

According to Edward III, communication is defined as "the process of delivering communicator information to the communicant". According to Edward III, information regarding public policies needs to be conveyed to policy actors so that policy actors can know what they must prepare and do to carry out the policy so that policy goals and objectives can be achieved as expected [7]. According to Edward III, policy communication has several dimensions, including transmission, clarity, and consistency [15]. The results of survey data processing can be presented in the image below:

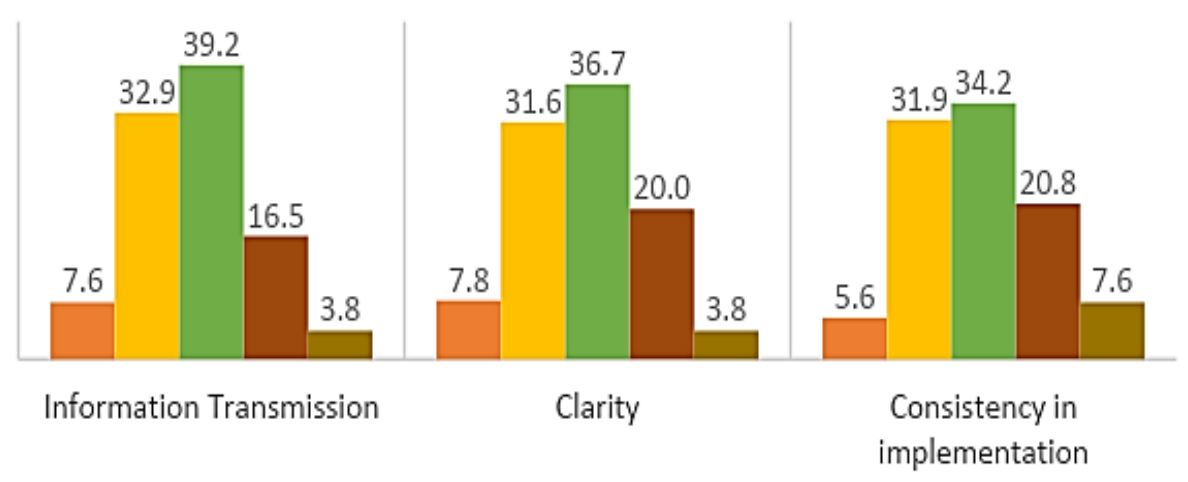

Excellent $\square$ Good $\square$ Satisfactory $\square$ Less Satisfactory $\square$ Poor

Fig. 1. Distribution of Respondents' Answers Regarding Communication Variables

The dimension of information transmission requires that public policies be conveyed to policy implementers and policy target groups, and other interested parties. From the data obtained, it can be seen that respondents who gave a satisfactory answer were more dominant $(39.2 \%)$ than the second dominant was good to answer $(32.9 \%)$; this shows that the tendency of respondents to assess the implementation of this policy is still in the range of good scores, although not optimal. In the dimension of clarity, policies should be transmitted to implementers, target groups, and other interested parties clearly so that among them know what the aims, objectives, targets, and substance of the public policy are so that each will know what is being said must be 
prepared and implemented to make the policy effective and efficient. In this aspect, the dominant respondents gave answers in the excellent category $(36.7 \%)$ and the excellent category (31.6\%). It appears that most of the respondents considered the policy implementation process to be good, although not optimal. Similar conditions also appear to occur in the consistency dimension, and this dimension is needed so that the policies taken are not confusing to confuse policy implementers, target groups, and interested parties. In this dimension, it appears that the dominant respondents gave answers in the excellent category $(34.2 \%)$ and the excellent category $(31.9 \%)$, so it can be understood if this dimension in the implementation of the policy is considered good even though it is not in optimal condition.

\section{2) Resources}

Edward III suggests that resource factors have an essential role in policy implementation. According to Edward III, these resources include human resources, budget resources, equipment resources, and authority resources [16]. These four resources are then analyzed and explained based on the survey results that have been conducted. The presentation of the data can be seen from the image below:

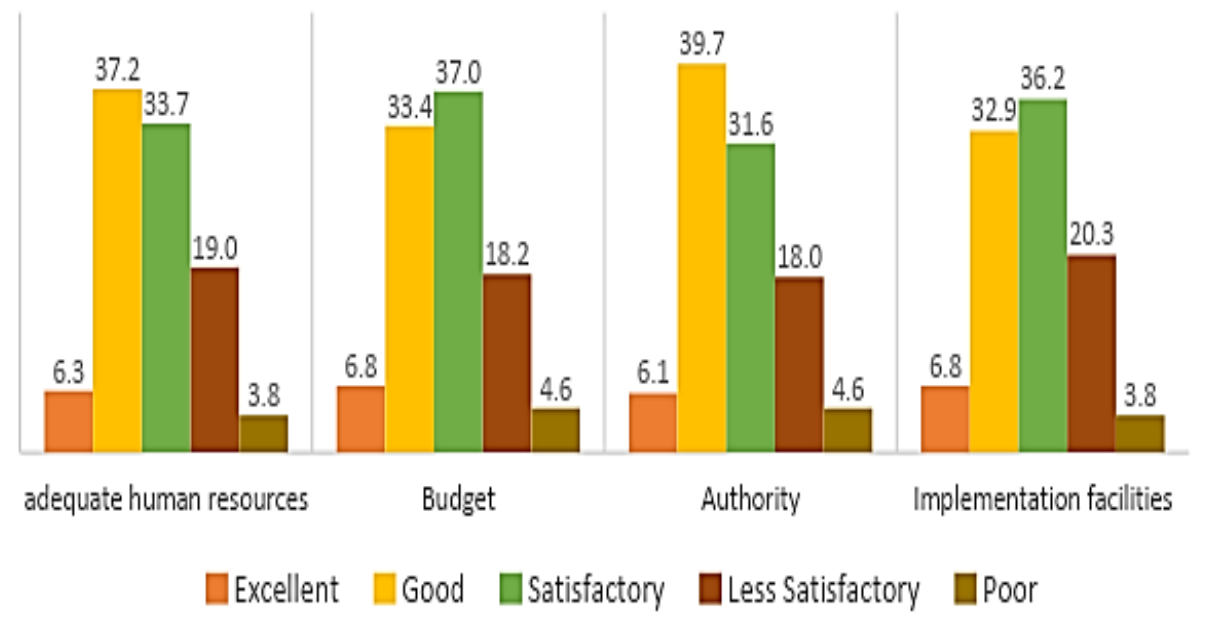

Fig. 2. Distribution of Respondents' Answers Regarding Resources Variables

Resources are one of the variables that affect the success of policy implementation. Edward III adds that no matter how clear and consistent the order of implementation is, and no matter how accurately they are transmitted, implementation will not be effective if the personnel responsible for implementing policies lacks the resources to do an adequate job [13]. Respondents' assessment in this dimension appears to be dominant in the good $(37.2 \%)$ and satisfactory $(33.7 \%)$. This condition is also marked by the third dominant portion in the unsatisfactory category $(19.0 \%)$.

According to Edward III, Budget Resources, the limited available budget causes the quality of services provided to the community to be personals limited. The little incentives given to implementers are the leading cause of the failure of program implementation [11]. Edward III concludes that limited budget resources will affect the success of policy implementation. Besides, the program cannot be implemented optimally, and budget constraints cause the disposition of policy actors to be below [8]. In the implementation of this policy, an exciting composition of answers appears, where the dominant respondents answered satisfactory (37.0\%) and the good category (33.4\%), and the less satisfactory category $(18.2 \%)$. This composition also seems to indicate the assessment of respondents who consider the implementation of the policy to be good, although not yet optimal.

Authority resources are pretty necessary for determining the success of policy implementation is authority. Edward III states that sufficient authority to make their own decisions will influence the institution in implementing a policy. Edward III states that the main policy actors must be given sufficient authority to make decisions to implement the policies under their authority [17]. From the survey results, it appears that the dominant respondents answered in the good category (39.7) and satisfactory (31.6), while the answers in the unsatisfactory category were in third place $(18.0 \%)$. It indicates that the respondent considers that the implementation of this policy is exemplary even though it is not optimal.

Resources Equipment/Facilities for implementation in Edward III's opinion, equipment resources are the means used to operationalize the implementation of a policy that includes buildings, land, and facilities, all of which will make it easier to provide services in policy 
implementation [4]. From the survey results, it appears that the dominant respondents chose answers in the excellent category $(36.2 \%)$ and the satisfactory category $(32.9 \%)$, and the unsatisfactory/poor category $(20.3 \%)$. This composition indicates that the respondent considers that the implementation of this policy is exemplary even though it is not optimal.

\section{3) Disposition}

According to Edward III, the definition of disposition is "the willingness, desire, and tendency of policy actors to carry out the policy seriously so that what is the policy goal can be realized". Edward III says that: if policy implementation is to succeed effectively and efficiently, implementors not only know what to do and have the ability to implement the policy, but they must also have the will to do so. To implement the policy [12]. Factors that are of concern to Edward III regarding disposition in policy implementation consist of; (1). Implementation Compliance, (2). Task Suitability, and (3). Implementation Incentives. The respondents then assess these three factors, and the distribution of the answers can be observed from the following figure:

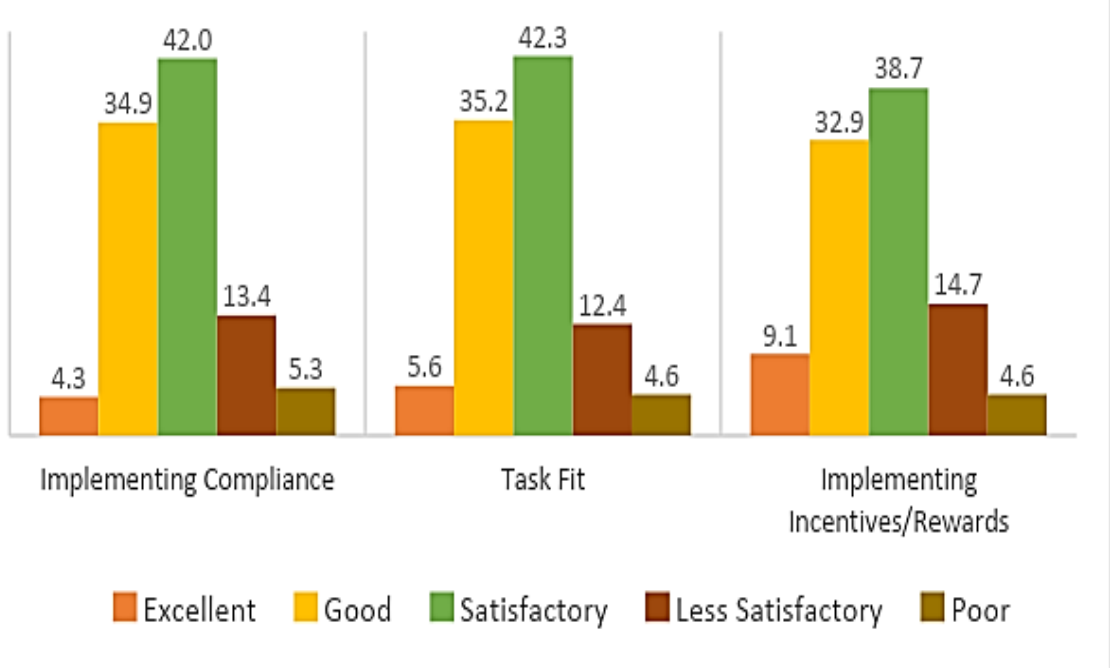

Fig. 3. Distribution of Respondents' Answers to Dispositions Variable

In the implementation compliance dimension, it can be understood that related to the disposition or attitude of the implementers. It will cause natural obstacles to policy implementation if the existing personnel does not implement the policies desired by higher officials. Based on the data from the survey, it appears that the dominant respondents chose answers in the excellent category $(42.0 \%)$ and the excellent category $(34.9 \%)$ and unsatisfactory (13.4\%). It indicates that the dominant respondents consider implementing this policy to be good, although not optimal. Similar conditions appear in the dimension of task suitability. This dimension is related to the appointment and selection of personnel implementing policies, which must be dedicated to the policies that have been set, more specifically to the interests of the community. The survey results show that the dominant respondents are in the satisfactory category $(42.3 \%)$ and the good category $(35.2 \%)$, and the unsatisfactory category (14.7\%). A similar pattern also appears in the dimension of implementation incentives. Incentive implementation is one of the suggested techniques to overcome the attitude problem of policy implementers by manipulating incentives. The form of its application is to increase sure profits or costs, and it may be a driving factor that makes the implementers carry out orders well. The survey results show that the dominant respondents choose the satisfactory category (38.7\%) and the good category (32.9\%) and less than satisfactory $(14.7 \%)$. A similar understanding can be identified in this dimension, that the dominant respondent considers the implementation of this policy to be good, although not optimal.

\section{4) Bureaucratic Structure}

Edward III states that policy implementation may still be ineffective because of the inefficiency of the bureaucratic structure [7]. According to Edwards III, there are two main characteristics of bureaucracy: Standard Operational Procedure (SOP) and distribution of responsibilities or fragmentation. These two characteristics or dimensions are then assessed by respondents and produce a distribution of answers that can be observed in the image below: 


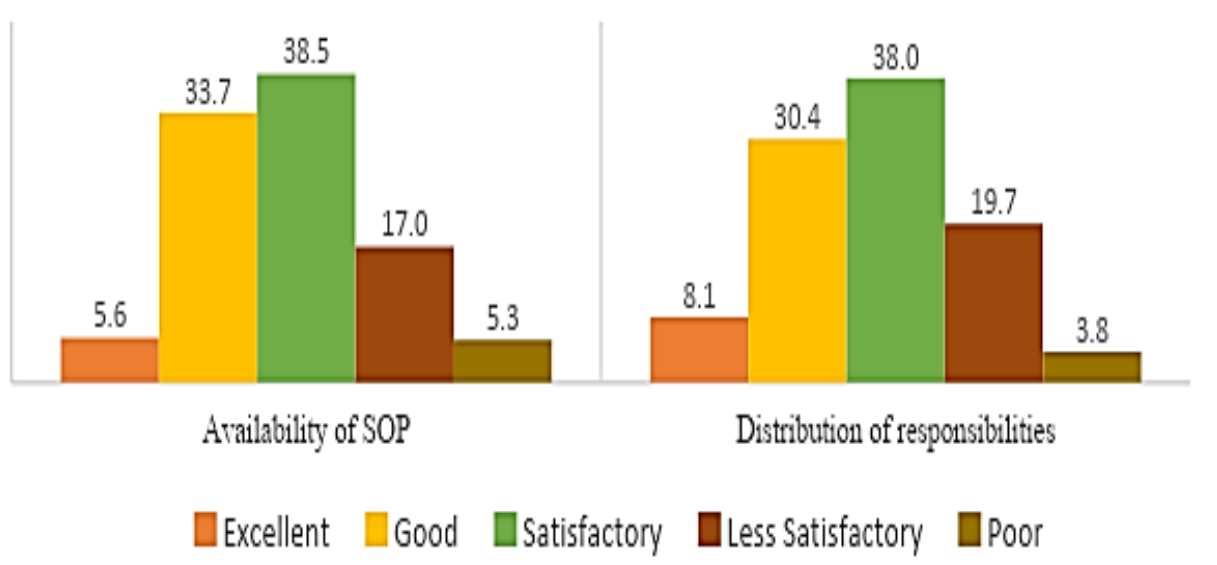

Fig. 4. Distribution of Respondents' Answers in Bureaucratic Structure Variables

According to Edward III stated that whether or not operating standards are clear, both regarding mechanisms, systems, and procedures for implementing policies, division of primary tasks, functions and authorities, and responsibilities among actors, and the harmonious relationship between implementing organizations with one another also determines the success of policy implementation [18]. From the survey conducted, it appears that the dominant respondents chose the satisfactory category (38.5\%) and the good category (33.7\%), and the unsatisfactory category $(17.0 \%)$. This composition shows that if the dominant respondent considers the policy to be running well, it is not yet optimal.

Meanwhile, the dimension of the distribution of responsibility is related to the more significant the policy requires changes in the usual ways in an organization, the greater the probability of SOPs hindering the implementation of Edward III explaining that "fragmentation is the distribution of responsibility for a policy to several groups or different bodies that require coordination" [19]. Edward III said that a fragmented bureaucratic structure (split or scattered ed.) could increase communication failure because the opportunity for its instructions to be distorted is enormous [2]. The more distorted policy implementation is, the more intensive coordination is needed". From the survey results, it appears that the dominant respondents chose the satisfactory category $(38.0 \%)$ and the good category $(30.4 \%)$ and less than satisfactory $(19.7 \%)$. It has the same pattern as the previous dimension and can be interpreted in the same way.

\section{CONCLUSION}

Overall, respondents' assessment of the implementation of this policy is in the satisfactory, good, and unsatisfactory categories. It indicates that respondents assess the policy implementation process that is considered good, even though it is not optimal. The balance of answers in the range of the three categories indicates if the implementation of the policy has been carried out but is felt to experience various obstacles observed or felt by the respondents. Based on the distribution of respondents' answers, it is deemed necessary to improve several aspects of the implementation of the policy, including; (1). Clarity of information conveyed to the public, (2) Consistency in policy implementation, (3). Adequacy of human resources involved in policy implementation, (4). Implementation facilities for policy implementation, (5). Compliance in policy implementation and (6). Availability of SOPs used in the policy implementation process. These aspects require the initiation of regional leaders and stakeholders in overseeing the implementation process to maintain the achievement of the policy objectives.

\section{REFERENCES}

[1] I. M. Agung, 'Memahami Pandemi Covid-19 Dalam Perspektif Psikologi Sosial', Psikobuletin:Buletin Ilmiah Psikologi, vol. 1, no. 2, Art. no. 2, May 2020, doi: 10.24014/pib.v1i2.9616.

[2] S. A. Wahab, ANALISIS KEBIJAKAN: dari Formulasi ke Penyusunan Model-Model Implementasi Kebijakan Publik. Bumi Aksara, 2021.

[3] M. Mulyadi, 'Implementasi Kebijakan Pengadaan Tanah untuk Kepentingan Umum di Jakarta Utara', Aspirasi: Jurnal Masalah-masalah Sosial, vol. 8, no. 2, Art. no. 2, Apr. 2019, doi: https://doi.org/10.46807/aspirasi.v8i2.1262.

[4] C. Ansell, E. Sørensen, and J. Torfing, 'Improving policy implementation through collaborative policymaking', Policy \& Politics, vol. 45, no. 3, pp. 467-486, Jul. 2017, doi: 10.1332/030557317X14972799760260.

[5] C. Vaupell, I. Wakkee, and P. Van Der Sijde, 'The University's Role in Sustainable Development: Activating Students as Agents of Change', Proceedings, vol. 2017, no. 1, p. 12083, Aug. 2017, doi: 10.5465/AMBPP.2017.12083abstract.

[6] B. Hudson, D. Hunter, and S. Peckham, 'Policy failure and the policy-implementation gap: can policy support programs help?', Policy Design and Practice, vol. 2, no. 1, pp. 1-14, Jan. 2019, doi: 10.1080/25741292.2018.1540378.

[7] M. Howlett, 'Moving policy implementation theory forward: A multiple streams/critical juncture approach', Public Policy and 
Administration, vol. 34, no. 4, pp. 405-430, Oct. 2019, doi: $10.1177 / 0952076718775791$.

[8] H. K. Colebatch, Handbook on Policy, Process and Governing. Edward Elgar Publishing, 2018.

[9] U. Farida, E. Wagiyanto, M. Bustamin, and R. Salam, 'Analysis of Empowerment Program that was Implemented in Mamuju Regency East Sulawesi Indonesia', Sep. 2017, pp. 19 21. doi: 10.2991/icest-17.2017.7.

[10] U. Melin and E. Wihlborg, 'Balanced and integrated egovernment implementation - exploring the crossroad of public policy-making and information systems project management processes', Transforming Government: People, Process and Policy, vol. 12, no. 2, pp. 191-208, Jan. 2018, doi: 10.1108/TG-12-2017-0080.

[11] E. Klaster, C. P. M. Wilderom, and D. R. Muntslag, 'Balancing Relations and Results in Regional Networks of Public-Policy Implementation', Journal of Public Administration Research and Theory, vol. 27, no. 4, pp. 676-691, Oct. 2017, doi: 10.1093/jopart/mux015.

[12] G. Capano, M. Howlett, M. Ramesh, and A. Virani, Making Policies Work: First- and Second-order Mechanisms in Policy Design. Edward Elgar Publishing, 2019.
[13] F. Fischer and G. J. Miller, Handbook of Public Policy Analysis: Theory, Politics, and Methods. Routledge, 2017.

[14] P. John and G. Stoker, 'Rethinking the Role of Experts and Expertise in Behavioural Public Policy', Policy \& Politics, vol. 47, no. 2, pp. 209-226, Apr. 2019, doi: 10.1332/030557319X15526371698257.

[15] M. Maor, 'Strategic Policy Overreaction as a Risky Policy Investment', International Review of Public Policy, vol. 1, no. 1:1, Art. no. 1, Jun. 2019, doi: 10.4000/irpp. 277.

[16] M. Merad and B. D. Trump, 'The legitimacy principle within French risk public policy: A reflective contribution to policy analytics', Science of The Total Environment, vol. 645, pp. 1309-1322, Dec. 2018, doi: 10.1016/j.scitotenv.2018.07.144.

[17] M. Maor, 'Deliberate disproportionate policy response: towards a conceptual turn', Journal of Public Policy, vol. 41, no. 1, pp. 185-208, Mar. 2021, doi: 10.1017/S0143814X19000278.

[18] W. N. Dunn, Public Policy Analysis: An Integrated Approach. Routledge, 2017.

[19] P. Lutz, 'Variation in policy success: radical right populism and migration policy', West European Politics, vol. 42, no. 3, pp. 517-544, Apr. 2019, doi: 10.1080/01402382.2018.1504509. 